\title{
RESEARCH
}

\section{THE CATEGORY OF VOICE IN VIETNAMESE: A SYSTEMIC FUNCTIONAL DESCRIPTION}

\author{
Hoang Van Van* \\ VNU University of Languages and International Studies, \\ Pham Van Dong, Cau Giay, Hanoi, Vietnam \\ Received 1 October 2020 \\ Revised 5 November 2020; Accepted 12 January 2021
}

\begin{abstract}
This article is a functional description of the category of voice - arguably, one of the most slippery notions in the grammar of Vietnamese that seems to resist any satisfactory treatment. The theoretical framework employed for describing and interpreting the category is Systemic Functional Linguistics (SFL). Three questions which form the basis of this study are: (1) "Does the system of VOICE exist in Vietnamese?"; if so, (2) "What are the delicate options available in the environment of VOICE in Vietnamese?"; and (3) "How can these delicate options be distinguished from the SFL perspective?" The answers to these questions show that unlike formal grammatical descriptions, VOICE exists in Vietnamese as a system; the environment of VOICE opens up a number of delicate options; and these delicate options can be distinguished along the three metafunctions: experiential, interpersonal, and textual. The answers to these questions also show that SFL is a highly relevant framework for describing and interpreting the system of VOICE in Vietnamese: SFL helps us investigate the category from a number of dimensions, enabling us to have a more comprehensive view of it. The study contributes to the application of SFL to the description of Vietnamese grammar - a non-Indo-European language, opening up new potentials for a comprehensive approach to the description of a Systemic Functional Grammar of Vietnamese for research, application, and teaching purposes.
\end{abstract}

Key words: voice in Vietnamese, ergativity, transitivity, mood, theme

\section{Introduction}

The study of Vietnamese, since the introduction of traditional and formal Westernstyles of linguistics, has been hampered by the perception that "In Vietnamese, there are no articles, nouns, pronouns, verbs; there are no genders and numbers either, only words; these words are all mono-syllabic and in general invariable; their meanings are changed by the positions of the words which precede or follow them, i.e. by their functions or positions in the sentence"1 (Grammont \& Le, 1911, pp. 201-2; as cited in Nguyen, 1977, p. 14). With regard to

\footnotetext{
* Tel.: 84-946296999

Email:vanhv@vnu.edu.vn; vanhv.sdh@gmail.com

${ }^{1}$ Ibid., p. 14. This passage, which I have translated here for presentation, appears in the Vietnamese original as follows:

Trong tiếng Việt không có mạo từ, danh từ, đại từ, động từ, cũng không có giống, số, mà chỉ có những từ không thôi; những từ này đều là đơn âm tiết, nói chung không biến đổi, ý nghĩa của chúng được thay đổi hay được xác định nhờ những từ đặt trước hay theo sau, nghĩa là, nhò̀ chức năng, vị trí của chúng trong câu.
}

voice, although the issue has been occasionally raised at seminars and conferences on Vietnamese linguistics and Vietnamese language teaching about whether or not this category exists in Vietnamese, it is under-researched. In reviewing the literature, it is evident that almost no systematic research on voice has ever been conducted. It is either mentioned in passing in some Vietnamese textbooks for foreigners (e.g. Bouchet, 1912; Nguyen, 1979) or briefly described in some grammar books, implicitly using some single aspect of formal grammars as the theoretical framework (e.g. Nguyen, 1977; Diep, 1987, 2013). One of the consequences is that their descriptions of voice in Vietnamese appear to be superficial and inadequate; and, to make matters worse, an exhaustive and coherent application of a particular linguistic model to the description of voice in Vietnamese has not been possible. This is the reason why in this article we will attempt a description and interpretation of the category of voice in Vietnamese, using SFL as the theoretical framework. Our study consists of five main sections. Section one introduces the topic. 
Section two provides an overview of some formal conflicting views on voice in Vietnamese. Section three is concerned with data collection procedure and presentation of illustrative examples. Section four, drawing on insights from the studies by Halliday (1985, 1998, 2012, and elsewhere) and Halliday and Matthiessen (2014), describes and interprets in some detail the system of VOICE and its delicate options in Vietnamese. Finally, Section five summarises what has been explored and recommends the relevance of the SFL theory to description of Vietnamese grammar.

\section{Voice in Vietnamese: Conflicting views}

Formal grammarians of Vietnamese are not unanimous in looking at the category of voice in Vietnamese. To date, there have been three contradicting views about whether or not the category is applicable to the language. Some grammarians such as Truong (1867), Bui

(1a) [active]

$\begin{array}{lc}\text { Giáp } & \text { đánh } \\ \text { Giap } & \text { beat } \\ \text { NP1 } & \text { V(main) }\end{array}$

Giap beat(s) the horse.

(1b) [passive]

$\begin{array}{cc}\text { Con } & \text { ngupa } \\ \text { generic classifier } & \text { horse } \\ \text { NP2 } & \end{array}$

The horse is/was beaten by Giap.

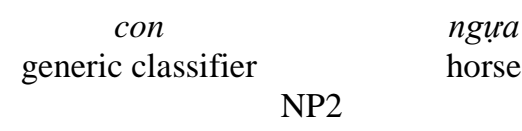

However, there are some grammarians (e.g., Bouchet, 1912; Cordier,1932, Tran et al., 1960; Emeneau, 1951; Le, 1980; Thompson, 1985) who, drawing mostly on the classical Western view, have expressed doubts about the existence of voice in Vietnamese. They argue against the need to recognise this category. To quote Emeneau (1951, pp. 63-4):

Of the Vietnamese verb in general, it may be said, as Yuen Ren Chao said for Chinese (Mandarin Primer, p. 35): "there is no distinction of voice in Chinese." Besides what looks like syntactically expressed voice ("direction of action") in the familiar Indo-European sense ("active" : "passive", Vietnamese has the type of direction [...], with object but no subject, and the types of construction $[\ldots]$ in which a verb is followed by and object and that in which it is followed by another verb in series. None of these involve formal change in verb, and claims:
(1952), Diep (1987, 2013) hold that the category of voice does exist in Vietnamese. They mention (in passing) that the distinction between what has been traditionally referred to as the active and passive voice rests on two conditions which generally coincide: (a) the difference in the structure corresponding to the active and passive voice in the clause and (b) the occurrence of the two traditionally called common passive verbs $b i$ (suffer, sustain, undergo) and đươc (get, obtain, receive). Simplifying somewhat, the different structures corresponding to the active and passive voice in Vietnamese, using the terminology of formal grammar, can be represented respectively as follows (note: $\mathrm{NP}=$ noun phrase; $\mathrm{V}=$ verb):

$\mathrm{NP} 1+\mathrm{V}$ (main) $+\mathrm{NP2} \quad$ [active] $\mathrm{NP} 2+\mathrm{V} 1$ (passive) + NP1 + V2 (main) [passive]

These contrasting constructions can be exemplified again in formal terms by the following clauses taken from Nguyen (1977, p. 132). $\mathrm{NP2}$ ngura
horse

$\begin{array}{cc}\text { Giáp } & \text { đánh } \\ \text { Giap } & \text { beat } \\ \text { NP1 } & \text { V2(main) }\end{array}$

it must be said that the Vietnamese verb is without the category of voice.

Emeneau (ibid., p. 73) continues to state:

Tense, mode, and voice, [...] are not the categories of the Vietnamese verb; nor are aspect, number and person of the subject and object. The verb has its class meaning: it occurs and can occur as the nucleus of a predicate and cannot occur as the subject of a predicate or as object of a verb, except when the verb of the predicate is là (be).

In a similar vein, Thompson (1985, p. 217)

An important way in which Vietnamese verbs differ from English verbs is that they do not in themselves imply a clear notion of "voice" in the grammatical sense. In English a (transitive) verb must be either active or passive. No such distinction is necessary in Vietnamese. As a matter of fact, the actor or the goal or object of 
Vietnamese verbs are regularly not formally marked; these relationships are generally clear from the context, and if they are not there are ways in which they can be made clear; the point is that they need not be, and in the vast majority of Vietnamese sentences such classifying devices are not used. The device which indicates that a preceding focal complement is actually a goal or object of the action [...].

Thus, the rejection of the category of voice in Vietnamese is said to be justified by the fact that voice is the category of the verb, and that because Vietnamese is an isolating/analytic or

(2)

$\begin{array}{cccc}\text { Bác } & H a i & b i & m o ̂ t \\ \text { uncle } & \text { Hai } & \text { suffer } & \text { one } \\ \text { NP1 } & & \text { VP } & \end{array}$

Uncle Hai got a gun shot.

(3)

$\begin{array}{lcc}\text { Quân } & \text { được } & \text { điểm } \\ \text { Quan } & \text { get/receive } & \text { mark } \\ \text { NP1 } & \text { VP } & \end{array}$

Quan got a good mark.

The fact that $b i$ and $d u o^{\circ} c$ can and do function as fully notional verbs has resulted in the third position which holds that although Vietnamese does not employ functional or morphological means, it uses syntactic means

(4)

$\begin{array}{ccc}\text { Pha }(. .) & \text { bung } & \text { mâm } \\ \text { Pha }(\ldots) & \text { bring } & \text { tray } \\ \text { NP1 } & \text { VP } & \text { NP2 } \\ \text { Subject } & \text { Predicate } & \text { Object }\end{array}$

Pha brought the food tray into the house.

(5)

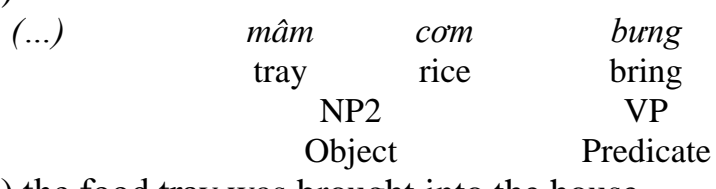

(...) the food tray was brought into the house,

According to Nguyen (Ibid.), in clause (4)

Pha is the actor, bung (brought) is the verb expressing an action, and mâm (the food tray) is the object which is affected by the action expressed by the verb bung. From the point of view of syntactic structure, this would be represented by the formal grammarian as Subject + Predicate + Object + Adverbial modifier of place. There is, however, an inversion of syntactic order in (5). In (4) mâm (the food tray), which is NP2, follows the verb bung (brought) and functions as the Object; however, in (5) mâm com (the food tray) which is still said to be NP2 functions as the Subject non-inflectional language, verbs in Vietnamese do not change in form to distinguish between the active and passive voices as those in many Indo-European languages. Further, it has been argued that the two most common forms $b i$ and aroọc (see examples (1a) and (1b) above), which have been referred to as the 'passive particles' (Emeneau, 1951; Thompson, 1985), are, to use the traditional terminology, 'fully notional verbs' (Nguyen, 1977, p. 196). In many respects, they can still be used as transitive verbs (Nguyen, 1979, p. xii) in the sentence. Examples (2) and (3) serve to illustrate the point (note: $\mathrm{NP}=$ noun phrase; $\mathrm{VP}=$ verb phrase; $\mathrm{A}=$ Adverb):

$\begin{array}{cc}\text { phát } & \text { súng lục } \\ \text { generic classifier } & \text { pistol } \\ \text { NP2 } & \end{array}$

\section{tốt \\ good \\ NP2}

(structure) to express the passive meaning (Nguyen, 1977; Diep, 2013). Below I shall reproduce two more examples taken from Nguyen (1977, p. 207) to show how the voice contrast in Vietnamese is explained as seen from the point of view of the third position:

$$
\begin{gathered}
\text { lên } \\
\text { up } \\
\text { A } \\
\text { Adverbial modifier } \\
\text { lên, } \\
\text { up } \\
\text { A } \\
\text { Adverbial modifier }
\end{gathered}
$$

and precedes the verb bung. Nguyen claims that the inversion of the order of the NP expressing the Object in clause (4) so that it acts as the Subject and precedes the verb in clause (5) indicates that the clause is passive. Nguyen (1977, p. 208) states:

In sentence 1 (= clause 4 here) the actor (of the action) and the subject (of the sentence) are conflated; this permits us to say that the verb bung expresses the active meaning. In sentence 2 (= clause 5 here), however, the noun mâm com, which expresses the object (in clause 4), functions as the subject. So it would be justified to say that this sentence 
is a passive one. The passive meaning, which is expressed by the whole syntactic structure as such, is not confined to the form of the verb but to the whole structure of the sentence. ${ }^{2}$

Nguyen's consideration of the active/passive distinction in terms of the different functions the subject plays in the sentence is crucial. It suggests that voice in Vietnamese is a feature of the clause, not of the verb, thus reflecting the specificity of Vietnamese as a non-inflectional language where verb form does not show whether a verb is active or passive. Further, what seems to be of theoretical importance is that his view represents a shift in focus from looking at the category of voice in Vietnamese totally from the point of view of the internal morphological structure of the verbal group (leading as a result to the claim that voice does not exist in Vietnamese) to viewing it from the point of view of the syntactic structure of the clause (leading as a result to the claim that voice exists in Vietnamese): in other words, the emphasis has shifted from (verb) morphology to (clause) syntax.

As can be seen from the above overview, scholars studying Vietnamese grammar have different views on the category of voice; some say that voice does exist in the language, while others hold that voice does not. What should be noted here is that those who recognize the existence of the voice base their interpretations only on one-faceted formal criterion. One of the consequences is that the picture of voice in Vietnamese appears to be inadequate. What is really needed is a comprehensive and coherent functional, social model of language that can help describe and interpret this important grammatical category in Vietnamese. This remark takes us to the next section where we will be concerned with the description and interpretation of voice in Vietnamese from the SFL perspective.

\footnotetext{
${ }^{2}$ Ibid., p. 208. This passage, which I have translated here for presentation, appears in the Vietnamese original as follows:

Trong câu 1 , chủ thể của hoạt động và chủ ngữ của câu trùng với nhau, và điều đó cho phép ta khẳng định được rằng động từ bung lên có ý nghĩa chủ động. Còn ở câu 2 , danh từ biểu thị đối tượng lại làm chủ ngữ của câu. Vì vậy có thể khẳng định rằng câu này có ý nghĩa bị động. Những ý nghĩa bị động biểu thị bằng cả một cấu trúc cú pháp nhu vậy không phải là dạng bị động của riêng động từ mà là ý nghĩa bị động của cả câu.
}

\section{Data collection and descriptive strategies}

\subsection{Data collection}

Voice is a grammatical category construed at the rank of the clause. A clause, as always, is part of a text. It follows that the illustrating material in this study should be text-based, with examples taken from natural texts (both written and spoken). Ideally, every example should be the whole text; but in practice this ideal is unattainable. So in order to exemplify, I scour short extracts or passages from complete texts which are understandable even apart from their contexts; and from these extracts, I choose the target clauses as examples for illustration.

In this study, the majority of examples are authentic. They are taken from a variety of genres: folk poetry, poems, short stories, and grammar books of Vietnamese. I have decided not to base the study on a particular corpus, because a grammatical aspect of the clause is concerned not just with the actual or observed examples but with the possible examples as well (cf. Chomsky, 1965).

Some other examples are my own; they are provided based on my knowledge as a competent native speaker of Vietnamese. This was made necessary for two reasons. First, when a number of grammatical points need to be illustrated in one and the same example (clause), often it is difficult to find an instance in a given collection of texts. This does not mean that the imaginary example cannot occur, but simply because of 'the vast complexity of language' (cf. Palmer, 1980, p. 8), it would take a grammarian a lifetime to scour the texts for it while as a native speaker of the language he or she knows very well that the example in question is a 'good' clause in his or her language. And secondly, when I wish to compare an example with a possible variant, such agnate pair(s) is/are also unlikely to occur in the language, but it seems that to search for such a minimally contrasting pair would be taking the use of authentic examples to unnecessary extremes.

As the majority of examples are taken from natural texts, they sometimes contain elements which are irrelevant to the point under discussion. In some instances, in order to avoid overload of information not needed immediately, what we have done is (i) to "tidy 
up' the original example by removing the irrelevant elements, and (ii) to expand the elements of an elliptical example, so as to remove ellipsis. It is hoped that these 'editing' steps, taken minimally, in no way invalidate the suitability of the examples, especially where the grammar of voice is concerned.

\subsection{Presentation of illustrative examples}

As this study is concerned only with a category of the clause of Vietnamese grammar, two notes of caution should be introduced before we could start. First, in the the SFL model (Halliday, 1967a, 1967b, 1968, 1970, 1978, 1985, 1998; Halliday \& Matthiessen, 2014; and many others), the clause is recognized as a simultaneous representation of three different strands of meaning: experiential, interpersonal and textual, realized at once in the system of transitivity (experiential), mood (interpersonal), and theme (textual). This suggests that in starting to examine the category of voice from the transitivity system, we have to presuppose the existence of other two systems such as mood and theme $\mathrm{e}^{3}$ in Vietnamese. However, at some point when there is a need to bring out more clearly an issue concerning the category of voice some reference will be made to them and other aspects of the grammar of Vietnamese. Further, as mood and theme have not been extensively described in Vietnamese from the SFL perspective, while recognizing the shortcomings of taking these for granted, we have generally assumed that functions such as Subject, Predicator, Complement, Adjunct, Theme, Rheme, Given, and New at least at the primary level of delicacy resemble those in English. And secondly, because the description of the category of voice in Vietnamese presented in this study is written in English, it should be presented in a way so that not only Vietnamese but also English readers can understand it. To fulfil this goal, glosses and symbols used in the article are presented as follows: in the descriptive and explanatory text, the initial letter of the names of functions is capitalized; e.g., Actor, Goal, Beneficiary, etc. When they are introduced for the first time, they appear in bold type and are usually followed by abbreviations enclosed in round

\footnotetext{
3 The Vietnamese transitivity system and its delicate subsystems such as material, behavioural, mental, verbal, relational, and existential have been described by Hoang $(1997,2012)$
}

brackets (...): Actor (Ac), Agent (Ag), Medium (Med), and so on. In contrast, names of systems are capitalised throughout: TRANSITIVITY for the system of TRANSITIVITY, MOOD for the system of MOOD, and so on.

The presentation of an illustrative example is organised as follows: each individual example is numbered in Arabic numeral which is enclosed in round brackets, followed by the source of data or the origin of the example which is enclosed in square brackets [...] (see Appendix); the first line, which is italicised, provides the Vietnamese wording; the second line gives English interglosses; the third line provides the configuration of functions of the elements in the clause and appear in bold type (where there is limited space, these functional labels are presented in abbreviated forms, but where there is enough space, they are presented in full); and the fourth represents an idiomatic translation into English. For non-Vietnamese speakers so far as the grammar is concerned, it is the inter-glosses that are more relevant and not the idiomatic translation, as the idiomatic translation is an attempt to convey the meaning and not the grammatical relations within the Vietnamese clause. Below is an instance of how an example is presented (note: $[\mathrm{TÐ}]=$ Tản Đà):

(0) [ТĐ]

\begin{tabular}{|c|c|c|c|c|}
\hline$L a ́$ & thu & roi rụng & dầu & ghềnh \\
\hline leaf & autumn & fall & head & chute \\
\hline Actor/Medium & $\begin{array}{c}\text { Process: } \\
\text { material }\end{array}$ & $\begin{array}{c}\text { Circumstance: } \\
\text { location }\end{array}$ \\
\hline
\end{tabular}

Autumn leaves fell on top of the chute.

\section{Voice in Vietnamese: A systemic functional description and interpretation}

\subsection{The notions of transitivity and ergativity}

We begin to explore the category of voice in Vietnamese with the examination of the notions of transitivity and ergativity because these notions have been the central topic of discussion of both formal and functional scholars (e.g. Svartvik, 1966; Fillmore, 1968; Lyons, 1979; Palmer, 1980; Kaplan, 1995; Collins Cobuild, 1996; Diep, 1987, 2013; Nguyen, 1977; Nguyen, 1979; Halliday, 1976, 1985 , 1998; Halliday \& Matthiessen, 2014; Matthiessen, 1995; Davidse, 1992; Hoang, 1997, 2012, and many others). Of the two notions of transitivity and ergativity in Vietnamese, ergativity has not yet been explored in the SFL model. Therefore, as a basis for exploring ergativity, it would be useful to start with the notion of transitivity. Consider the following examples taken from Hoang (2012). 
(6) [NM]

\begin{tabular}{|c|c|}
\hline$H \check{a ̆ n}$ & đến \\
\hline $\mathrm{He}$ & come \\
\hline Actor & Process: material \\
\hline
\end{tabular}

He came.

(7) $[\mathrm{NM}]$

\begin{tabular}{|c|c|c|}
\hline Hằn & đánh & Tuyét \\
\hline he & beat & Tuyet \\
\hline Actor & Process: material & Goal \\
\hline
\end{tabular}

He beat Tuyet.

(8) [TDP]

\begin{tabular}{|l|c|c|}
\hline Ông & già & thở dài \\
\hline $\mathrm{Mr}$ & old & sigh \\
\hline \multicolumn{2}{|l|}{ Behaver } & Process: behavioural \\
\hline
\end{tabular}

The old man sighed.

(9)

\begin{tabular}{|c|c|c|}
\hline Me & nhin & con \\
\hline mother & look & son \\
\hline Behaver & Process: behavioural & Phenomenon \\
\hline
\end{tabular}

The mother looked at her son.

(10)

\begin{tabular}{|c|c|c|}
\hline Nga & $n g h \tilde{\imath}$ & miên man \\
\hline Nga & think & interminably \\
\hline Senser & Process: mental & Circumstance \\
\hline
\end{tabular}

Nga thought interminably.

(11) [NM]

\begin{tabular}{|c|c|c|}
\hline Tuyét & $y \hat{e} u$ & $t o ̂ i$ \\
\hline Tuyet & love & I \\
\hline Senser & Process: mental & Phenomenon \\
\hline
\end{tabular}

Tuyet loved me.

(12)

\begin{tabular}{|c|c|c|c|}
\hline$H o ̣$ & thắc mắc & $v \hat{e}$ & chính sách \\
\hline they & complain & about & policy \\
\hline Sayer & Process: verbal & Circumstance \\
\hline
\end{tabular}

They complained about the policy.

(13) [NMC]

\begin{tabular}{|c|c|c|}
\hline Toà án & kết tội & kẻ giết ngưòi \\
\hline court & accuse & murderer \\
\hline Sayer & Process: verbal & Target \\
\hline
\end{tabular}

The court accused the murderer.

(14) [TH]

\begin{tabular}{|c|c|c|c|c|}
\hline Con & chim & gáy & (verbless) $^{4}$ & hiền lành \\
\hline $\begin{array}{c}\text { generic } \\
\text { classifier }\end{array}$ & bird & crowing & & gentle \\
\hline \multicolumn{3}{|c|}{ Carrier } & & Attribute \\
\hline
\end{tabular}

The turtle-dove is gentle.

\footnotetext{
${ }^{4}$ Several features of verbs in Vietnamese are quite different from those of verbs in English. The class does include a great majority of words which may be translated by English verbs. A large number of forms which are most conveniently rendered by English adjectives following some form of the verb 'be': thus Con chim gáy hiền lành means (The turtle-dove is gentle), Tôi vui (I am happy), Cô ấy buồn (She was sad), and so forth. The meaning 'be' seems to represent an integral part of the semantic range of this sort of verb (for more detail, see Thompson, 1985).
}

(15) [NHT]

\begin{tabular}{|c|c|c|}
\hline$T o \hat{i}$ & là & Nhâm \\
\hline I & be & Nham \\
\hline Identified/Token & $\begin{array}{c}\text { Process: } \\
\text { relational }\end{array}$ & Identifier/Value \\
\hline
\end{tabular}

I'm Nham.

(16) [CD]

\begin{tabular}{|c|c|c|c|c|}
\hline Trên & giời & có & đám mây & xanh \\
\hline on & sky & have & cloud & blue \\
\hline Circumstance & $\begin{array}{c}\text { Process: } \\
\text { existential }\end{array}$ & \multicolumn{2}{|c|}{ Existent } \\
\hline
\end{tabular}

There is a blue cloud in the sky.

The above examples are intended to demonstrate two important points. First, they are the process types which have been recognized in the experiential grammar of Vietnamese (see Hoang, 1997, 2012), of which (6) and (7) are material processes; (8) and (9) behavioural processes; (10) and (11) mental processes, (12) and (13) verbal processes, (14) and (15) relational processes, and (16) is an existential process. Secondly, of these processes, (6), (8), (10), (12), (14), and (16) involve one participant referred to respectively as Actor in (6), Behaver in (8), Senser in (10), Sayer in (12), Carrier in (14) and Existent in (16); and (7), (9), (11), (13), and (15) involve two participants referred to respectively as Actor and Goal in (7), Behaver and Phenomenon in (9), Senser and Phenomenon in (11), Sayer and Target in (13), and Identified/Token and Identifier/Value in (15). The fact that a process may involve one or two participants has constituted a basis for the distinction which is traditionally captured in grammars by the terms 'intransitive' and 'transitive'. The traditional claim that an intransitive clause has one participant, and a transitive clause has two poses some problem, since the second half of the generalisation does not hold because of the parameter of VOICE. Consider the following set of material clauses:

(17a)

\begin{tabular}{|c|c|}
\hline Cüa & $m o ̛$ \\
\hline door & open \\
\hline Actor & Process: material \\
\hline \multicolumn{2}{|c|}{ The door opened. }
\end{tabular}

(17b)

\begin{tabular}{|c|c|c|}
\hline Cừ̀ng & $m o ̛$ & của \\
\hline Cuong & open & door \\
\hline Actor & Process: material & Goal \\
\hline
\end{tabular}

Cuong opened the door. 


$(17 \mathrm{c})$
\begin{tabular}{|c|c|c|c|}
\hline Cưa & đuợc & (Cuờng) & $m o^{\prime}$ \\
\hline door & passive particle & (Cuong) & open \\
\hline Goal & & Actor & Process: material \\
\hline
\end{tabular}

The door was opened (by Cuong).

(17a) is traditionally known as an intransitive clause; (17b) is a transitive and active clause; and (17c) is a transitive and passive clause. Thus, according to the analysis the transitive clause has two possible patterns: active and passive. However, it should be noted that the Actor, Cuòng in (17b) is still introduced as the Actor in (17c) though is now preceded by the form $d u o^{\circ} c$, traditionally known in Vietnamese linguistic scholarship as 'passive particle'. The active/passive contrast is applicable only if the clause is transitive, and while it is possible for the Actor to occur overtly in either case as (17b) and (17c) show, when the clause is passive, the participant that is obligatory is Goal, not Actor, a situation that is indicated in (17b) and (17c) by putting the Actor, Cuơng, in round brackets. Let us refer to the perspective presented above as the transitive analysis. Halliday (1967a, 1967b, 1968, 1976, 1998, 2012), Halliday and Matthiessen (2014), and Matthiessen (1995) have pointed out that there does exist an alternative perspective on clause organization. They refer to it as the ergative perspective. What is ergativity and what distinguishes it from transitivity?

"The root of the grammar of the nuclear TRANSITIVITY of processes and participants are two simultaneous systems, PROCESS TYPE and AGENCY" (Matthiessen, 1995, p. 206). The former is specifically related to the transitive model and the latter, to the ergative one. Halliday (1970, p. 157, 1998, p. 167) and Halliday and Matthiessen (2014, p. 347) claim that these two alternative perspectives on clause organization are very widely distributed; possibly all languages display both, in different mixtures, with perhaps one or the other as the more dominant.

The transitive system realises a 'PROCESS AND EXTENSION model' (Davidse, 1992, p. 108; see also Halliday, 1977, 1998, 2012; Halliday \& Matthiessen, 2014; Hoang, 1997, 2012). Its point of departure (taking the material process as representative) is that the Actor is engaged in the process. If the action ends with the Actor as in Cây rung (The tree shook), then we have an intransitive clause realised by a structural configuration of Actor $^{\wedge}$ Process, where Actor can also be interpreted as the participant being 'affected' (Halliday, 1970, p. 157) by the action. However, the action does not have to stop at the Actor ${ }^{\wedge}$ Process combination. It can be extended to or directs itself on to a Goal as cây (tree) in Gió rung cây (The wind shook the tree). In such an instance, we have a transitive clause realised by a structural configuration of Actor $^{\wedge} \operatorname{Process}^{\wedge} \mathbf{G o a l}$, where Goal now is that which is to be interpreted as the participant being affected by the process. Whether the structure is Actor^Process as Cây rung (The tree shook) or Actor ${ }^{\wedge}$ Process $^{\wedge}$ Goal as Gió rung cây (The wind shook the tree), cây (the tree) still functions as something at which the action rung (shook) directs. Thus, if asked: Cái gì thế? (What happened?) or Cái cây làm sao thế? (What happened to the tree?), it would be reasonable to be told in response either that Nó (cái cây) rung (It [the tree] shook) or that Gió rung nó (The wind shook it [the tree]). In the first case, the action of shaking is represented as confined to the tree; in the second case, the action of shaking extends from the wind to the tree. Thus the transitivity model is based on 'extension'. Its basic question is 'whether the action extends beyond the actor or not' (cf. Halliday, 1968, p. 185; Halliday, 1976, 1998; Halliday \& Matthiessen, 2014).

With the ergative system, the picture is quite different. The ergative system is said to be typically generalised and cuts across the various process types (Halliday, 1998, p. 164; Matthiessen, 1995, p. 206). To use Davidse's (1992, p. 109) expression, the ergativity system realizes an 'INSTIGATION OF PROCESS model'. In this model, there is one participant that is the key figure in the process - the Medium (Med), defined by Halliday (1998, p. 163) as 'one through which the process is actualised, and without which there would be no process at all'. A clause is middle (mid) if the process is presented as 'internally instigated' (Davidse, 1992, p. 109) or 'self-engendering' (Halliday, 1998, p. 164; Halliday \& Matthiessen, 2014, p. 342): only the key participant and the process are expressed in it. Thus, Cúa mơ (The door opened), Cây đổ (The tree fell), and Cây rung (The tree shook) are all middle clauses and have 
the same structural configuration of Medium^^Process. In contrast, a clause is effective (eff) if the process is represented as 'externally instigated' (Davidse, ibid., p. 109); it is represented as if there were an external Agent (Ag), or Instigator, causing the process to happen. Thus Gió rung cây (The wind shook the tree), Cương mơ cưa (Cuong opened the door), and Hắn đánh Tuyết (He beat Tuyet) are all effective clauses and have

\section{Figure 1}

Transitive and Ergative Patterning in Vietnamese Transitive patterning

\begin{tabular}{c|c|c} 
Intransitive: & $\begin{array}{c}\text { Examples: } \\
\text { Cây rung (The tree shook) } \\
\text { Transitive: }\end{array} \quad \begin{array}{c}\text { Actor`}^{\wedge} \text { Process } \\
\text { Actor }^{\wedge} \text { Process }\end{array}$
\end{tabular}

\section{Ergative patterning}

\begin{tabular}{rl|l|} 
Middle: & $\begin{array}{l}\text { Medium }^{\wedge} \text { Process } \\
\text { Effective: }\end{array}$ \\
Process $^{\wedge}$ Medium
\end{tabular}

As can be seen in Figure 1, each model has its own form of organisation. In the transitive model, the process is inherently accompanied by the obligatory Actor and the optional Goal which is indicated by the notation \pm . In the ergative model, on the other hand, the obligatory participant that is centrally involved in the Process is the Medium and the optional one is the Agent. Halliday (1998, pp. 165-66) and Halliday and Matthiessen (2014, pp. 343-44) have shown, in relation to English which can also be applicable to Vietnamese, that the ergative function of Medium - 'the nodal participant throughout the system' (Halliday, 1998, p. 165; Halliday and Matthiesen, 2014, p. 343) turns up in all types of process. It is equivalent to:

Actor in middle material process; e.g. (18)

\begin{tabular}{|c|c|}
\hline Thằng bé & $n g \tilde{a}$ \\
\hline little boy & fall \\
\hline Medium/ Actor & Process: material \\
\hline
\end{tabular}

The little boy fell.

Goal in effective material clause; e.g. (19)

\begin{tabular}{|c|c|c|}
\hline Thằng bé & đá & quả bóng \\
\hline little boy & kick & ball \\
\hline Agent/ Actor & & Medium/ Goal \\
\hline
\end{tabular}

The boy kicked the ball. the same structural configuration of Agent/Instigator ${ }^{\wedge}$ Process $^{\wedge}$ Medium. So unlike the transitive model, the ergative model is based on 'causation'. Its basic question is 'whether the cause/instigation is external to the action or not' (Halliday 1968, 1970, 1998; see also Matthiessen, 1995; Halliday \& Matthiessen, 2014; Hoang, 1997, 2012). Below is a schema representing the two alternative models of transitivity and ergativity in Vietnamese.

\author{
Cây rung (The tree shook) \\ Gió rung cây (The wind shook the tree)
}

Behaver in behavioural process; e.g. (20) [TDP]

\begin{tabular}{|c|c|c|}
\hline Ho & uống & cả ngày \\
\hline they & drink & whole day \\
\hline $\begin{array}{c}\text { Medium/ } \\
\text { Behaver }\end{array}$ & $\begin{array}{c}\text { Process: } \\
\text { behavioural }\end{array}$ & Circumstance \\
\hline
\end{tabular}

They drank the whole day.

Senser in mental process; e.g.

\begin{tabular}{|c|c|c|c|}
\hline Ngừ̀i & già & thích & thoải mái \\
\hline people & old & like & comfort \\
\hline $\begin{array}{c}\text { Medium/ } \\
\text { Senser }\end{array}$ & $\begin{array}{c}\text { Process: } \\
\text { mental }\end{array}$ & Phenomenon \\
\hline
\end{tabular}

Old people like comfort.

Sayer in middle verbal process; e.g. (22)

\begin{tabular}{|c|c|c|c|}
\hline Ông $\hat{\text { áy }}$ & nói & về & lịch $s \dot{u}^{\prime}$ \\
\hline he & talk & about & history \\
\hline $\begin{array}{c}\text { Medium/ } \\
\text { Sayer }\end{array}$ & $\begin{array}{c}\text { Process: } \\
\text { verbal }\end{array}$ & Circumstance \\
\hline
\end{tabular}

He talked about history.

Target in effective verbal process; e.g. (23)

\begin{tabular}{|c|c|c|c|}
\hline Nhiều & nguòi & ca ngơi & ông \\
\hline many & people & praise & he \\
\hline \multicolumn{2}{|c|}{ Agent/ Sayer } & $\begin{array}{c}\text { Process: } \\
\text { verbal }\end{array}$ & Medium/Target \\
\hline
\end{tabular}

Many people praised him. 
Carrier in attributive relational process; e.g. (24)

\begin{tabular}{|c|c|}
\hline $\boldsymbol{H} \hat{\boldsymbol{o}}$ & $d \tilde{u}$ \\
\hline Tiger & fierce \\
\hline Medium/ Carrier & Attribute \\
\hline
\end{tabular}

A tiger is fierce.

Identified in identifying relational process; e.g.

\begin{tabular}{|c|c|c|c|}
\hline \\
\hline$C \hat{o}$ & Chi & là & giáo viên \\
\hline Ms & Chi & be & teacher \\
\hline \multicolumn{2}{|c|}{$\begin{array}{l}\text { Medium/ } \\
\text { Identified }\end{array}$} & $\begin{array}{l}\text { Process: } \\
\text { relational }\end{array}$ & Identifier \\
\hline
\end{tabular}

Ms Chi is the teacher.

Existent in existential process; e.g.

(26) [CD]

\begin{tabular}{|c|c|c|c|c|}
\hline Trên & giời & có & đám mây & xanh \\
\hline on & sky & have & cloud & blue \\
\hline Circumstance & $\begin{array}{c}\text { Process: } \\
\text { existential }\end{array}$ & \multicolumn{2}{|c|}{ Medium/ Existent } \\
\hline
\end{tabular}

There is a blue cloud in the sky.

In contrast, Agent appears as a function only where the process is instigated by an external agency. It is equivalent to:

Actor in effective material process; e.g. (27)

\begin{tabular}{|c|c|c|c|}
\hline Thằng & Trú & đốt & đền \\
\hline $\begin{array}{c}\text { generic } \\
\text { classifier }\end{array}$ & Tru & burn & temple \\
\hline Agent/ Actor & $\begin{array}{c}\text { Process: } \\
\text { material }\end{array}$ & Medium/Goal \\
\hline
\end{tabular}

Tru burned the temple.
Initiator when the Actor is present in effective material process; e.g.

(28)

\begin{tabular}{|c|c|c|c|}
\hline Gió & làm & cây & rung \\
\hline wind & make & tree & shake \\
\hline Agent/ & & Actor & $\begin{array}{c}\text { Process: } \\
\text { material }\end{array}$ \\
\hline
\end{tabular}

The wind made the tree shake.

Phenomenon in effective mental process of the encoded type (from Phenomenon to consciousness); e.g.

\begin{tabular}{|c|c|c|c|c|c|c|}
\hline $\begin{array}{l}\text { Lò̀i } \\
\text { nói }\end{array}$ & của & $\begin{array}{l}c \hat{o} \\
t a\end{array}$ & làm & $\begin{array}{l}\text { hài } \\
\text { lòng }\end{array}$ & cha & mẹ \\
\hline word & of & she & make & please & father & mother \\
\hline \multicolumn{3}{|c|}{$\begin{array}{c}\text { Agent/ } \\
\text { Phenomenon }\end{array}$} & \multicolumn{2}{|c|}{$\begin{array}{l}\text { Process: } \\
\text { mental }\end{array}$} & \multicolumn{2}{|c|}{$\begin{array}{c}\text { Medium/ } \\
\text { Senser }\end{array}$} \\
\hline \multicolumn{7}{|c|}{$\begin{array}{l}\text { Her words pleased her parents. } \\
\text { Sayer in effective verbal process; e.g. } \\
\text { (30) [NHT] }\end{array}$} \\
\hline \multicolumn{2}{|c|}{ Su Thiều } & & \multicolumn{2}{|c|}{ hỏi } & \multicolumn{2}{|c|}{ Quyên } \\
\hline \multicolumn{2}{|c|}{ Monk Thieu } & & \multicolumn{2}{|c|}{ ask } & \multicolumn{2}{|c|}{ Quyen } \\
\hline \multicolumn{2}{|c|}{$\begin{array}{l}\text { Agent/ } \\
\text { Sayer }\end{array}$} & \multicolumn{3}{|c|}{$\begin{array}{c}\text { Process: } \\
\text { verbal }\end{array}$} & \multicolumn{2}{|c|}{$\begin{array}{l}\text { Medium/ } \\
\text { Receiver }\end{array}$} \\
\hline
\end{tabular}

Monk Thieu asked Quyen.

Carrier in attributive relational process; e.g. (31) [HT]

\begin{tabular}{|c|c|c|c|}
\hline Con & chim & gáy & hiền lành \\
\hline $\begin{array}{c}\text { generic } \\
\text { classifier }\end{array}$ & bird & crowing & gentle \\
\hline \multicolumn{2}{|c|}{ Agent/ Carrier } & $\begin{array}{l}\text { Medium/ } \\
\text { Attribute }\end{array}$ \\
\hline
\end{tabular}

The turtle-dove is gentle.

Attributor when the Carrier is present in attributive relational process; e.g.

\begin{tabular}{|c|c|c|c|c|c|}
\hline Trò̀i & nóng & làm & hoa quả & chóng & chín \\
\hline sky & hot & make & fruit & quick & ripe \\
\hline Agent/ Attributor & & Carrier & Circumstance & Attribute \\
\hline
\end{tabular}

Hot weather made fruits ripe quickly.

Identifier/Token in identifying relational process; e.g.

(33) $[\mathrm{NHT}]$

\begin{tabular}{|c|c|c|}
\hline$T \hat{o} i$ & là & Nhâm \\
\hline I & be & Nham \\
\hline Agent/ Identified/ Token & Process: relational & Identifier/ Value \\
\hline
\end{tabular}

I am Nham.

Assigner in identifying relational process; e.g.

(34)

\begin{tabular}{|c|c|c|c|c|c|c|}
\hline Ho & bầu & thày & Năm & là & nhà giáo & uu tú \\
\hline they & elect & teacher & Nam & be & teacher & meritorious \\
\hline Agent/ Assigner & & \multicolumn{2}{|c|}{ Identified/ Token } & Process: relational & Identifier/ Value \\
\hline
\end{tabular}

They elected Mr Nam meritorious teacher.

Two other additional participants recognised in the transitive model are also recognised in the ergative model and are given the same labels: Range and Beneficiary. Range, defined as "scope or domain of the process"

(Matthiessen et al., 2010, p. 170) or a restatement of the process itself (Halliday, 1967a, 1968, 1998), often enters into the clause as a nominal group. It can be assigned a different label in a different clause type. Thus, Range is equivalent to: 
Range in middle material process; e.g. (35)

\begin{tabular}{|c|c|c|c|}
\hline Thày & Năm & choi & $\boldsymbol{c} \grave{\boldsymbol{o}}$ \\
\hline father & Nam & play & chess \\
\hline Agent/Actor & Process: material & Range \\
\hline
\end{tabular}

Father Nam plays chess.

(36)

\begin{tabular}{|c|c|c|c|c|c|}
\hline Ho & nhảy & $\boldsymbol{m} \hat{\underline{o} t}$ & $\begin{array}{c}\text { diệu } \\
\text { nhảy }\end{array}$ & rất & $\boldsymbol{l a}$ \\
\hline they & dance & one & dance & very & strange \\
\hline $\begin{array}{c}\text { Agent/ } \\
\text { Actor }\end{array}$ & $\begin{array}{c}\text { Process: } \\
\text { material }\end{array}$ & \multicolumn{4}{|c|}{ Range } \\
\hline
\end{tabular}

They danced/performed a very strange dance.

Behaviour in behavioural process; e.g.

(37)

\begin{tabular}{|c|c|l|c|}
\hline Bọn trẻ & đang & nghe & nhac \\
\hline children & $\begin{array}{c}\text { aspectual } \\
\text { marker }\end{array}$ & listen & music \\
\hline $\begin{array}{c}\text { Agent/ } \\
\text { Behaver }\end{array}$ & \multicolumn{2}{|c|}{$\begin{array}{c}\text { Process: } \\
\text { behavioural }\end{array}$} & $\begin{array}{c}\text { Range/ } \\
\text { Behaviour }\end{array}$ \\
\hline
\end{tabular}

The children are listening to music.

Phenomenon of the 'thích (like) type' in mental process; e.g.

(38)

\begin{tabular}{|c|c|c|}
\hline Tuyét & thích & tôi \\
\hline Tuyet & like & I \\
\hline $\begin{array}{c}\text { Agent/ } \\
\text { Senser }\end{array}$ & $\begin{array}{c}\text { Process: } \\
\text { mental }\end{array}$ & $\begin{array}{c}\text { Range/ } \\
\text { Phenomenon }\end{array}$ \\
\hline
\end{tabular}

Tuyet liked me.

Recipient in material process; e.g.

(42) [Recipient as direct participant]

\begin{tabular}{|c|c|c|c|c|c|c|}
\hline$T o \hat{i}$ & gưui & me & tôi & môt & món & $q u \grave{a}$ \\
\hline I & send & mother & I & one & generic classifier & present \\
\hline Agent/ Actor & Process: material & \multicolumn{2}{|c|}{ Recipient } & \multicolumn{4}{c|}{ Medium/Goal } \\
\hline
\end{tabular}

I sent my mother a present.

(43) [Recipient as indirect participant]

\begin{tabular}{|c|c|c|c|c|c|c|c|}
\hline$T \hat{o} i$ & $g u ̛ i$ & $m o ̣ ̂ t$ & $m o ́ n$ & $q u a ̀$ & cho & me & tôi \\
\hline I & send & one & generic classifier & present & to & mother & I \\
\hline Agent/ Actor & Process: material & \multicolumn{4}{|c|}{ Medium/Goal } & \multicolumn{3}{c|}{ Recipient } \\
\hline
\end{tabular}

I sent a present to my mother.

Client in material process; e.g.

(44)

\begin{tabular}{|c|c|c|c|c|c|}
\hline$H \tilde{a} n$ & $v \tilde{e}$ & búc & tranh & cho & me \\
\hline he & paint & generic classifier & picture & for & mother \\
\hline Agent/ Actor & Process: material & \multicolumn{2}{|c|}{ Medium/ Goal } & \multicolumn{2}{|c|}{ Client } \\
\hline
\end{tabular}

He painted a picture for his mother.

Receiver in verbal process; e.g.

(45) $[\mathrm{NHT}]$

\begin{tabular}{|c|c|c|c|}
\hline$S u$ & Thiều & hỏi & Quyên \\
\hline monk & Thieu & ask & Quyen \\
\hline \multicolumn{2}{|c|}{ Agent/ Sayer } & Process: verbal & Receiver \\
\hline
\end{tabular}

Monk Thieu asked Quyen.
Verbiage - "the content or kind of saying" (Halliday, 1998, p. 167) - in verbal process; e.g.

\begin{tabular}{|c|c|c|c|c|}
\hline Anh & goi & hai & li & ruọu \\
\hline he & call & two & glass & wine \\
\hline $\begin{array}{c}\text { Agent/ } \\
\text { Sayer }\end{array}$ & $\begin{array}{c}\text { Process: } \\
\text { verbal }\end{array}$ & \multicolumn{3}{|c|}{ Verbiage } \\
\hline
\end{tabular}

He ordered two glasses of wine.

Attribute in attributive relational process; e.g. (40)

\begin{tabular}{|c|c|c|c|c|c|}
\hline$C \hat{o}$ & $C h i$ & $l a ̀$ & một & cô giáo & tốt \\
\hline Ms. & Chi & be & one & $\begin{array}{c}\text { Ms } \\
\text { teacher }\end{array}$ & good \\
\hline \multicolumn{2}{|c|}{$\begin{array}{c}\text { Agent/ } \\
\text { Carrier }\end{array}$} & $\begin{array}{c}\text { Process: } \\
\text { relational }\end{array}$ & \multicolumn{3}{|c|}{ Attribute } \\
\hline
\end{tabular}

Ms. Chi is a good teacher.

Identifier/Value in identifying relational process; e.g.

\begin{tabular}{|c|c|c|c|}
\hline$C \hat{o}$ & $C h i$ & là & giáo viên \\
\hline $\mathrm{Ms}$ & $\mathrm{Chi}$ & be & teacher \\
\hline $\begin{array}{c}\text { Identified/ } \\
\text { Token }\end{array}$ & $\begin{array}{c}\text { Process: } \\
\text { relational }\end{array}$ & $\begin{array}{c}\text { Identifier/ } \\
\text { Value }\end{array}$ \\
\hline
\end{tabular}

Ms Chi is the teacher.

In contrast, Beneficiary, defined as "one that stands to gain" (Halliday, 1998, p. 167), may enter into the clause either directly as a nominal group or indirectly as a prepositional phrase. It can be equivalent to: 
Beneficiary in relational attributive process; e.g. (46)

\begin{tabular}{|c|c|c|c|c|c|}
\hline Phần thưởng & này & là & dành & cho & anh \\
\hline reward & this & be & reserve & for & brother \\
\hline Medium/ Carrier & Process: relational & \multicolumn{2}{|c|}{ Beneficiary } \\
\hline
\end{tabular}

This reward is for you.

\subsection{Voice in Vietnamese: A multifunctional interpretation}

The above discussion demonstrated that Vietnamese shows up in both the transitive and ergative systems, and each of these systems allows a more delicate systemic contrast. Figure 2 below shows the ergative and transitive as two concurrent systems with the system of process type for the Vietnamese clause: the ERGATIVE system is the entry condition for the options of middle $v$. effective, and the TRANSITIVE system is the entry condition for the options of intransitive v. transitive. The rationale for including both in the network is that they represent two complementary, not mutually exclusive, perspectives on clause organisation.

\section{Figure 2}

Ergative and Transitive Systems: Primary Choices

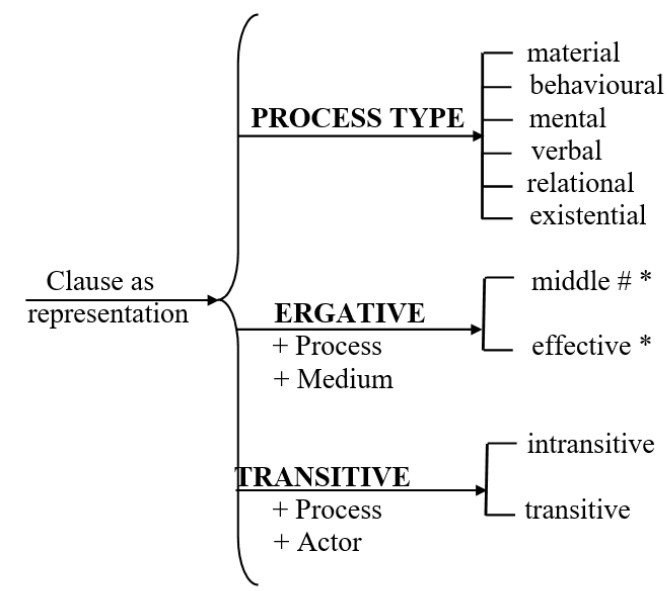

Conventions: \#: intransitive; * : transitive

Figure 2 is intended to show three points.

First, the system of PROCESS TYPE is the entry condition for the six clause options of material, behavioural, mental, verbal, relational, and existential; the ERGATIVE system is the entry condition for the options of middle $\mathrm{v}$. effective; and the TRANSITIVE system is the entry condition for the options of intransitive $v$. transitive. Secondly, a middle clause can be either intransitive (indicated by the notation \#) or transitive (indicated by the notation *), while an effective clause can be only transitive. And thirdly, voice can be interpreted either from the TRANSITIVE or the ERGATIVE system. Transitively, a clause is intransitive when it has one participant (the Actor in a material process, for instance), and the voice is active as Thày Năm in Thày Năm đi vào (Father Nam came in). In contrast, a clause is transitive when it has two participants - an Actor and a Goal, and the voice may be active as $\boldsymbol{C} \hat{a} \boldsymbol{u}$ bé and quả bóng in Cậu bé đá quả bóng (The boy kicked the ball) or passive as Quả bóng and cậu bé in $\boldsymbol{Q u a ̉}$ bóng được cậu bé đá (The ball was kicked by the boy). And ergatively, a clause is middle when it has no feature of agency; the clause is active; and it may have one participant - the Medium as $\boldsymbol{C} \hat{a} \boldsymbol{u}$ bé in $\boldsymbol{C} \hat{a} \boldsymbol{u}$ bé ngã (The little boy fell), or two participants - the Medium and an 'additional entity' which is not Goal because it "exists independently of the process and indicates the domain over which the process takes place" (Halliday, 1998, p. 146) referred to as Range as đàn ghi ta (guitar) in Anh ta choi đàn ghi ta (He played the guitar). In contrast, a clause is effective when it has the feature of agency, and the clause can be either active (or operative) as in Con chó đuổi con mèo (The dog chased the cat) or passive (or receptive) as in Con mèo bi con chó đuổi (The cat was chased by the dog).

However, looked at from a wider environment, it can be seen that the choice of voice is not just a matter of the experiential metafunction; it is a matter of the interpersonal and textual metafunctions as well (cf. Halliday, 1998, p. 167; Halliday \& Matthiessen, 2014). In what follows, we will argue that the explanation of voice requires reference to all the three metafunctions.

The active v. passive choice is, in effect, a textual resource in the sense that it allows certain thematic possibilities, which in its absence would not be available. This remark concerns in particular the question of unmarked v. marked theme where unmarked theme refers to unusual or normal theme and marked theme implies unusual or abnormal theme. Taking the major material declarative clause as the starting 
point, the constituent functioning as Subject will also have the function of unmarked Theme, so long as it is the first constituent with an experiential and interpersonal function as in:

(47a) [active voice]

\begin{tabular}{|c|c|c|c|c|c|}
\hline Anh $\hat{a} y$ & $s \tilde{e}$ & hoàn thành & luận án & năm & sau \\
\hline he & aspectual marker & complete & dissertation & year & after \\
\hline Actor & \multicolumn{2}{|c|}{ Process: material } & Goal & \multicolumn{2}{|c|}{ Circumstance } \\
\hline Subject & \multicolumn{2}{|c|}{ Predicator } & Complement & \multicolumn{2}{|c|}{ Adjunct } \\
\hline Theme (unmarked) & \multicolumn{5}{|c|}{ Rheme } \\
\hline
\end{tabular}

He will complete his dissertation next year.

The conflated realisation of these three functions - Actor/Subject/unmarked Theme - by the same constituent construes a specific kind of point of departure. An unmarked Theme construes a point of departure which is not in contrast to any other, and typically does not

function as New information. The conflation of Theme in a declarative clause with any element other than Actor/Subject will make the Theme marked, in the sense that it will construe a point of departure that is in some sense contrastive and/or presents New information as for example in:

(47b) [active voice]

\begin{tabular}{|c|c|c|c|c|c|}
\hline Luận án & anh ấy & sẽ & hoàn thành & năm & sau \\
\hline dissertation & he & aspectual marker & complete & year & after \\
\hline Goal & Actor & \multicolumn{2}{|c|}{ Process: material } & Circumstance \\
\hline Complement & Subject & \multicolumn{4}{|c|}{ Predicator } \\
\hline Theme (marked) & \multicolumn{4}{|c|}{ Rheme } \\
\hline New $\longleftarrow$ Gdjunct \\
\hline
\end{tabular}

His dissertation he will complete next year.

(47c) [active voice]

\begin{tabular}{|c|c|c|c|c|c|}
\hline Năm & sau & anh $\hat{a} y$ & sẽ & hoàn thành & luận án \\
\hline year & after & he & aspectual marker & complete & dissertation \\
\hline Circumstance & Actor & Process: material & Goal \\
\hline Adjunct & Subject & Predicator & Complement \\
\hline Theme (marked) & \multicolumn{4}{|c|}{ Rheme } \\
\hline Given
\end{tabular}

Next year he will complete his dissertation.

Note that the voice in all three clauses above is active. However, it is possible to choose as an unmarked Theme in a declarative clause something other than the constituent with the conflated function of Actor/Subject. In this case, however, the voice of the clause must be passive, for voice is a resource for re(47d) [passive voice]

\begin{tabular}{|c|c|c|c|c|c|c|}
\hline Luận án & $s \tilde{e}$ & duoocc & (anh $\hat{a} y)$ & hoàn thành & năm & sau \\
\hline dissertation & asp. marker & pass. marker & he & complete & year & after \\
\hline Goal & & & Actor & Process: material & \multicolumn{2}{|c|}{ Circumstance } \\
\hline Complement & & & Subject & Predicator & & unct \\
\hline Theme (unmarked) & \multicolumn{6}{|c|}{ Rheme } \\
\hline
\end{tabular}

His dissertation will be completed next year.

At this point, a question raised for exploration here is: How can the active and passive voice be distinguished? To facilitate the ordering of the experiential functions, with the result that with different voice choices, different experiential functions will conflate with different interpersonal ones. In particular, Subject in the passive clause will be conflated with Goal, and Actor may or may not be present as in: 
(48a)

\begin{tabular}{|c|c|c|c|c|}
\hline Cừng & náu & comm & này & ngon \\
\hline Cuong & cook & rice & this & delicious \\
\hline Actor/Agent & Process: material; effective & Goal/Medium & Circumstance \\
\hline Subject & Predicator & Complement & Adjunct \\
\hline Theme (unmarked) & \multicolumn{3}{|c|}{ Rheme } \\
\hline
\end{tabular}

Cuong cooked this rice well.

(48b)

\begin{tabular}{|c|c|c|c|c|c|}
\hline Cơm & này & đươc & (Cuòng) & náu & ngon \\
\hline rice & this & passive maker & Cuong & cook & delicious \\
\hline Goal/Medium & & Actor/Agent & Process: material; effective & Circumstance \\
\hline \multicolumn{2}{|c|}{ Subject } & & Adjunct & Predicator & Adjunct \\
\hline Theme (unmarked) & & \multicolumn{4}{|c|}{ Rheme } \\
\hline
\end{tabular}

This rice was well cooked (by Cuong).

Clause (48a) is transitive and active, and clause (48b) is transitive and passive. If these clauses are compared, it will be noted that they differ from each other in a number of respects.

From the point of view of recognition, there is a re-ordering of the participants in the passive version. Cuoòng, which is Actor/Agent and stands at the head of clause (48a), is still Actor/Agent but has moved to precede the Process in (48b); and com này (this rice), which is Goal/Medium and is preceded by the Process in clause (48a), is still (48c)

\begin{tabular}{|c|c|c|c|c|}
\hline Cơm & này, & Cưòng & náu & ngon \\
\hline rice & this & Cuong & cook & delicious \\
\hline \multicolumn{2}{|c|}{ Goal/Medium } & Actor/Agent & Process: material; effective & Circumstance \\
\hline \multicolumn{2}{|c|}{ Complement } & Subject & Predicator & Adjunct \\
\hline \multicolumn{2}{|c|}{ Theme (marked) } & \multicolumn{3}{|c}{ Rheme } \\
\hline
\end{tabular}

This rice, Cuong cooked well.

where Goal/Medium/Complement are brought to the head of the clause, and Theme is conflated with them: when Goal/Medium/Complement are conflated with Theme, Theme is no longer unmarked: it construes a point of departure which in some sense highlights it. The fact that there is a reordering of participants in the passive voice and this re-ordering opens up the different possibilities of conflation with Subject and Theme, leaving the thematic choices of the clause unmarked, is important: the definition criterion for the passive voice in Vietnamese is precisely the construal of Goal as the speaker's (48d)

\begin{tabular}{|c|c|c|c|c|}
\hline Com & này & duợc & nấu & ngon \\
\hline rice & this & passive marker & cook & delicious \\
\hline \multicolumn{2}{|c|}{ Goal/Medium } & & Process: material; effective & Circumstance \\
\hline \multicolumn{2}{|c|}{ Subject } & & Predicator & Adjunct \\
\hline \multicolumn{2}{|c|}{ Theme } & & Rheme & \\
\hline
\end{tabular}

This rice was well cooked.
Goal/Medium but has moved to the head of (48b). This re-ordering of participants in the passive clause has opened up the different possibilities of conflation with lexicogrammatical functions that are realisationally related to the interpersonal and textual metafunctions. Thus, instead of Actor/Agent as Subject/Theme where Theme is unmarked in clause (48a), we have Goal/Medium as Subject/Theme so that Theme is still unmarked in (48b). This is in contrast to an agnate clause such as point of departure without implying any highlighting for the information to which the element refers.

From the point of view of grammatical structure, (48b) can be distinguished from (48a) in two respects. First, like (48a), Actor/Agent Cuoòng is present as a direct participant in (48b); however, unlike (48a), it is not conflated with Subject/Theme but is mapped on to Actor/Agent which is part of Rheme. Further, the presence of Actor/Agent in (48a) seems to be obligatory while the presence of Actor/Agent in (48b) may be optional. Thus, it is possible to say either as (48b) or as the following:

\footnotetext{
The second distinction between a passive clause and an active one has to do with the
}

difference in the internal structure of the verbal group realising the Process in the passive 
clause. In (48a) the Process is realised by the verb nấu (cooked); in (48b), however, the Process is realised by a verbal group which consists of the same verb form nấu (cooked) and the traditionally known 'passive particle', or 'passive verb' đươc.
The above discussion suggests that there are both semantic and lexicogrammatical grounds for distinguishing the active from the passive voice in Vietnamese. The active/passive distinction can be represented in Figure 3.

\section{Figure 3}

The System of VOICE in Vietnamese: Active and Passive

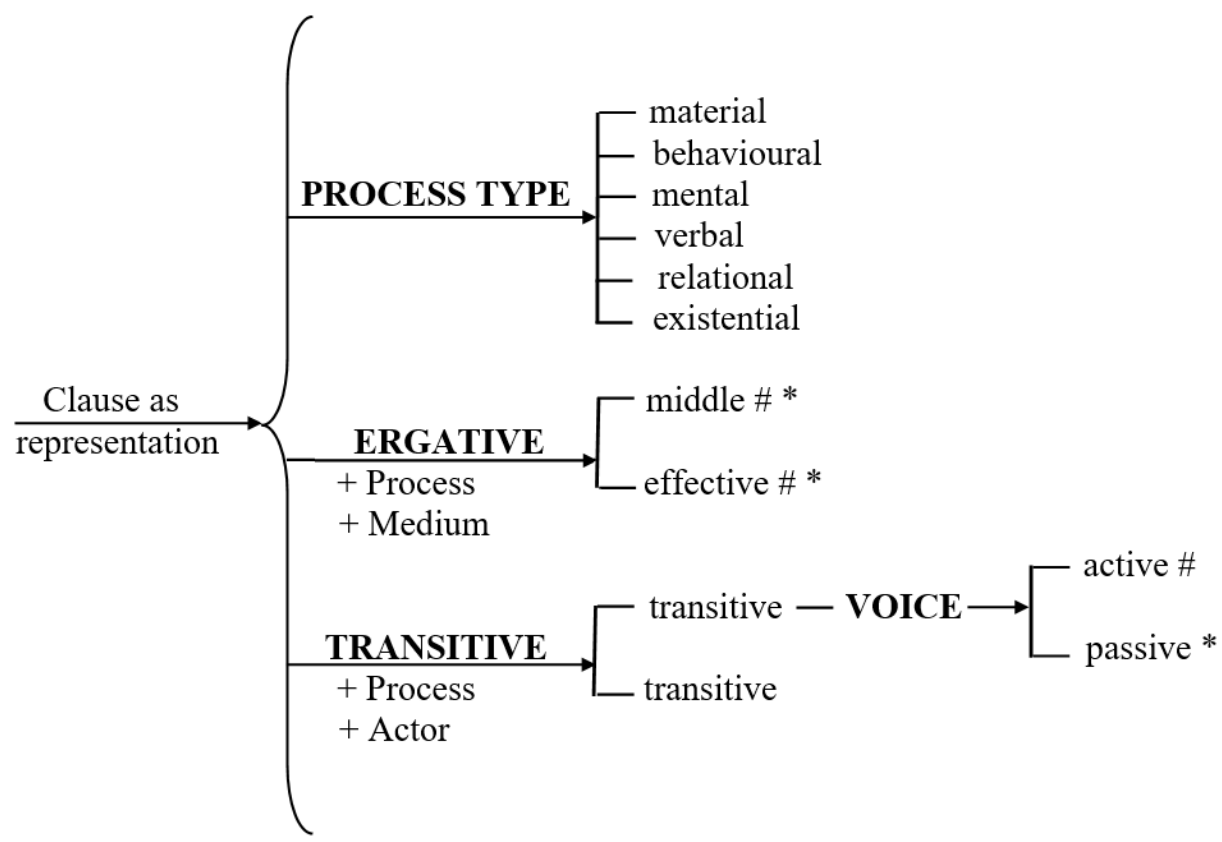

Conventions: $\#=$ active; $*=$ passive

\section{3. đực and bị: passive particles?}

In English, the construction of be $+\mathrm{V}$-en constitutes the main choice of passive, which seems to be attitudinally neutral. Thus we can have I am given; You are given, She is given, I was given, You were given, She was given, which are all attitudinally neutral seen from the point of view of the speaker, and it seems no further distinction can be made. In Vietnamese, however, the choice of passive constitutes the entry condition for two more delicate systemic options having the feature of [+attitude: judgement] (Martin \& White, 2005, p. 35), which can be referred to as 'desirable' v. 'undesirable'. These options can be exemplified in (49) and (50):

(49)

\begin{tabular}{|c|c|c|c|c|}
\hline Cơm & đươc & Cưòng & nấu & ngon \\
\hline rice & benefit & Cuong & cook & deliciously \\
\hline
\end{tabular}

The rice was well cooked by Cuong.

\begin{tabular}{|c|c|c|c|}
\hline Tuyét & $\boldsymbol{b} \dot{\boldsymbol{i}}$ & hắn & đánh \\
\hline Tuyet & suffer & he & beat \\
\hline
\end{tabular}

Tuyet was beaten by him.

'Desirable' and 'undesirable' can be distinguished on both semantic and lexicogrammatical grounds. Semantically, desirable refers to the meaning of 'benefiting' which has the feature of [+pleasant]. In contrast, undesirable refers to the meaning of 'suffering' which has the feature of [-pleasant]. Lexicogrammatically, each of these options is realised by a different form: desirable is realised by the form dugc which means 'benefit', 'gain', 'obtain', or 'receive', and undesirable is realised by the form $\boldsymbol{b} \boldsymbol{i}$, which means 'suffer', 'sustain', or 'undergo'. The desirable/undesirable contrast can be represented in the following system network: 


\section{Figure 4}

The System of VOICE in Vietnamese: Desirable and Undesirable

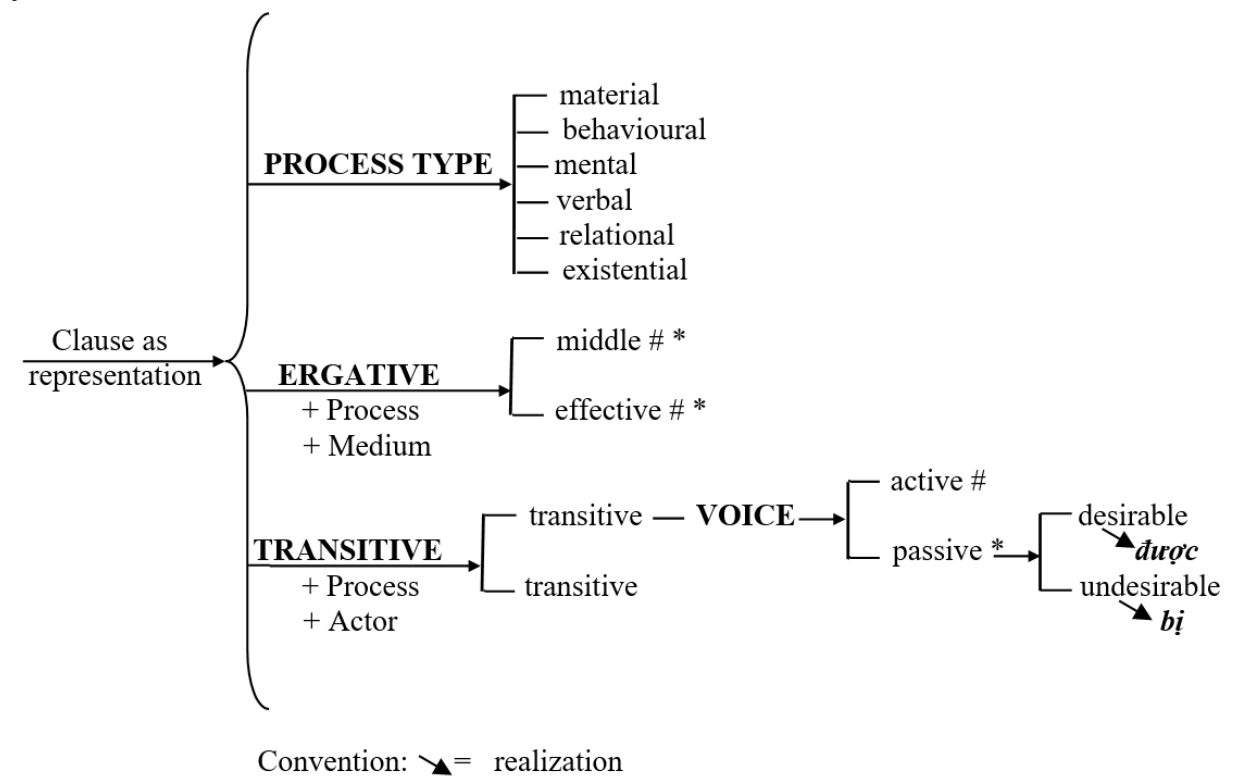

Figure 4 claims that in Vietnamese the choice between desirable v. undesirable (realised by $a u x c c$ and $b i$ respectively) is applicable if and only if the clause has feature [+passive]. This is obviously not true in the light of examples (2) and (3) above. There is however a difference between the use of duo ${ }^{\circ} \mathrm{c}$

and $b i$ in an active clause as opposed to a passive. This can be clarified by a consideration of the following examples:

(51) intransitive/middle

\begin{tabular}{|c|c|c|}
\hline Thằng bé & $\boldsymbol{b} \dot{\boldsymbol{i}}$ & $n g \tilde{a}$ \\
\hline little boy & suffer & fall \\
\hline
\end{tabular}

The little boy fell.

(52) transitive/middle/active

\begin{tabular}{|c|c|c|c|c|c|c|}
\hline Mình & $\widetilde{\text { duợc }}$ & $\breve{a} n$ & môt & bũa & sáng & ngon \\
\hline self/I & benefit & eat & one & generic classifier & morning & delicious \\
\hline
\end{tabular}

I had a delicious breakfast.

(53) transitive/effective/active

\begin{tabular}{|c|c|c|c|c|c|c|}
\hline Anh & $\boldsymbol{b} \dot{\boldsymbol{i}}$ & mất & một & chiếc & $\hat{o}$ & trắng \\
\hline he & suffer & lose & one & generic classifier & umbrella & white \\
\hline
\end{tabular}

He lost a white umbrella.

Compare now (51) - (53) with the following:

(51a) intransitive/middle

\begin{tabular}{|c|c|}
\hline Thằng bé & $n g \tilde{a}$ \\
\hline boy & fall \\
\hline
\end{tabular}

The boy fell.

(51a) transitive/middle/active

\begin{tabular}{|c|c|c|c|c|c|}
\hline Mình & $\breve{a} n$ & mọt & bũa & sáng & ngon \\
\hline self/I & eat & one & $\begin{array}{c}\text { generic } \\
\text { classifier }\end{array}$ & morning & delicious \\
\hline
\end{tabular}

I had a delicious breakfast.

(51c) transitive/effective/active

\begin{tabular}{|c|c|c|c|c|c|}
\hline Anh & mất & một & chiéc & $\hat{o}$ & trắng \\
\hline he & lose & one & $\begin{array}{c}\text { generic } \\
\text { classifier }\end{array}$ & umbrella & white \\
\hline
\end{tabular}

He lost a white umbrella.

It will appear clear that (51a), (52a) and (53a) are neutral while (51), (52), and (53) sound somewhat marked. This difference in marking can be attributed to the presence or absence of $d u r o c$ and $b i$ : in the active clause the presence of duơ $c$ or bi has the effect of making it marked.

The fact that desirable/undesirable may be present in all types of clause and that, except in the case of passive, their presence in clauses with the [+active] feature makes them sound marked suggests two points: (i) duroc $c$ and $b i$ are not passive particles per se but function in that capacity, and (ii) it may be possible to establish a separate system to account for the markedness of the presence of desirable/undesirable in clauses with the [+active] feature in Vietnamese. This system may be called MARKEDNESS, and the terms of the system are 'neutral' and 'marked'. The features 'marked' and 'passive' act as disjunctive entry conditions for the systemic choice between 'desirable' and 'undesirable': that is to say, the 
choice between the last two systemic features is applicable either in the environment of 'passive' or in the environment of 'marked' (for detail about semantic system network in SFL, see
Hasan, 1996). The system of MARKEDNESS with its more delicate choices in concurrence with the systems of PROCESS TYPE, ERGATIVE, and TRANSITIVE is represented in Figure 5.

\section{Figure 5}

The System of MARKEDNESS and its More Delicate Choices

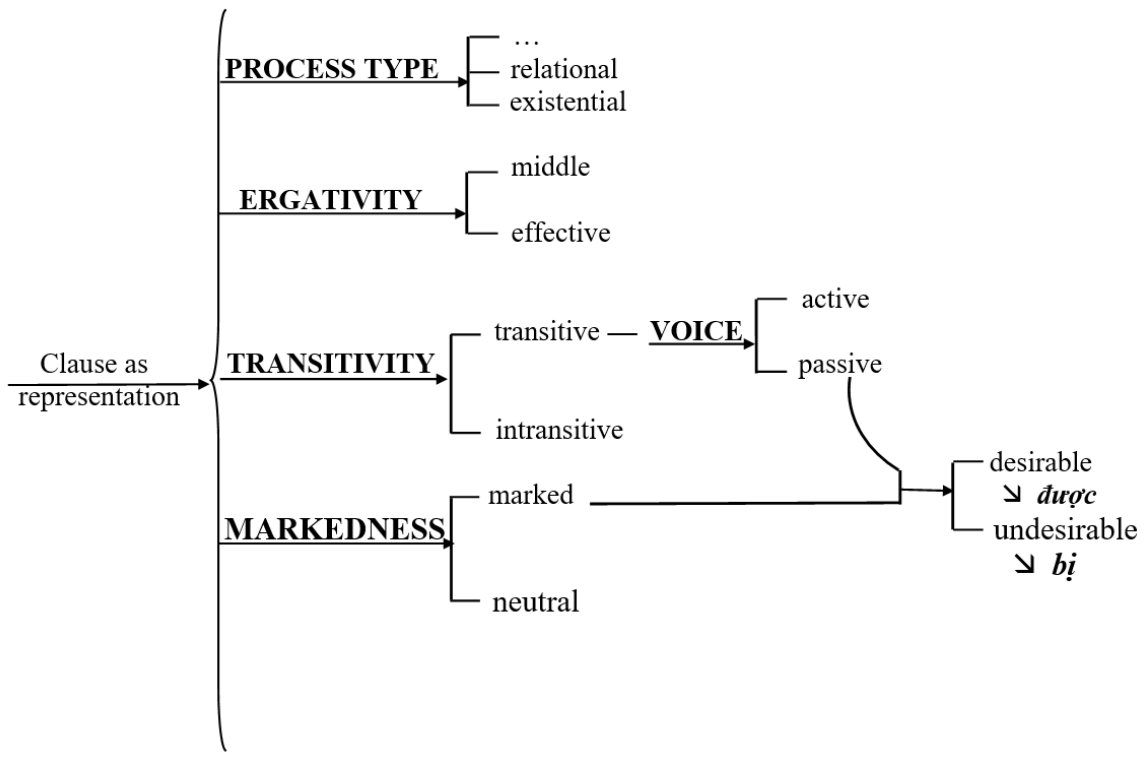

\section{Concluding remarks}

In this article, we have made an attempt to outline a description of one of the most important categories in the grammar of Vietnamese which does not seem to have received adequate attention from the Vietnamese linguistic scholarship: the category of voice. We began our discussion by presenting three formal contradicting views about whether or not voice is applicable to the language. Then drawing on insights from SFL, we have described and interpreted this category of voice in Vietnamese. We first examined voice in relation to the two alternative experiential perspectives: transitivity and ergativity. Then, using these perspectives as the basis, we took a step further, interpreting voice from a multifunctional approach, intertwining the experiential function with the interpersonal and the textual ones in the clause. In answering the first question "Does voice exist in Vietnamese?", we share the idea of some formal grammarians (e.g. Truong, 1867; Bui, 1952; Nguyen, 1977; Nguyen, 1979; and Diep, 1987, 2013; and others) that voice does exist in Vietnamese, and that it is a feature of the clause, rather than that of the verb. But, in answering the second and the third questions, "What are the delicate options available in the environment of VOICE in Vietnamese?", and "How can these delicate options be distinguished from the SFL perspective?", we differ markedly from formal grammarians. Offering a new approach to the description and interpretation of the Vietnamese voice - the SF approach, we have thus achieved new findings: first, VOICE in Vietnamese constitutes a system that runs across all types of ranking clause, and this system opens up a number of delicate choices: middle v. effective, if effective is chosen, it will allow two more delicate choices: active v. passive (voice), and if passive is chosen, it will further allow two more delicate choices: desirable v. undesirable. And secondly, these delicate choices can be distinguished along the three metafunctions of language: experiential (realized in transitivity and ergativity), interpersonal (realized in mood), and textual (realized in theme). It is clear from our research that to have a comprehensive picture of any grammatical category, we really need a multifunctional approach. And it is precisely this 
multifunctional approach that has justified the relevance of SFL to our study: by describing and interpreting the system of VOICE in Vietnamese from the SFL perspective, we are able to understand many features which otherwise remain arbitrary or obscure.

\section{References}

\section{Vietnamese}

Bùi Đức Tịnh (1952). Văn phạm Việt Nam [A grammar of Vietnamese]. Nhà xuât bản Phạm Văn Tươi.

Diệp Quang Ban (1987). Câu đơn tiếng Việt [The simple sentence in Vietnamese]. Nhà xuất bản Giáo dục.

Diệp Quang Ban (2013). Ngũ pháp Việt Nam [A grammar of Vietnamese]. Nhà xuât bản Giáo dục.

Halliday, M. A. K. (2012). Dẫn luận ngũ pháp chức năng [An introduction to Functional Grammar] (Hoàng Văn Vân dịch) (tái bản lần thứ hai). Nhà xuất bản Đại học Quốc gia Hà Nội. https://doi.org/10.25073/2525/vnufs.4229

Nguyễn Kim Thản (1977). Động tù trong tiếng Việt [Verbs in Vietnamese]. Nhà xuất bản Khoa học xã hội.

Trần Trọng Kim, Bùi Kỷ, \& Phạm Duy Khiêm (1940). Việt-Nam Văn-Pham [A grammar of Vietnamese] (tái bản lần thứ tám). Nhà xuất bản Tân Việt.

\section{English}

Chomsky, N. (1965). Aspects of the theory of syntax. The M. I. T. Press.

Collins Cobuild (1996). Grammar patterns 1: Verbs. HarperCollins Publishers.

Davidse, K. (1992). Transitivity/Ergativity: The Janus-headed grammar of actions and events. In M. Davies \& L. Ravelli (Eds.), Advances in Systemic Linguistics: Recent theories and practices (pp. 105-35). Pinter Publishers.

Emeneau, M. B. (1951). Studies in Vietnamese (Annamese) grammar. University of California Press.

Fillmore, C. (1968). The case for case. In E. Bach \& R. T. Harms (Eds.), Universals in linguistic theory (pp. 1-88). Holt, Rinehart and Winston.

Halliday, M. A. K. (1967a). Notes on transitivity and theme in English, Part 1. Journal of Linguistics, 3(1), 37-81.

Halliday, M. A. K. (1967b). Notes on transitivity and theme in English, Part 2. Journal of Linguistics, 3(2), 199-244.

Halliday, M. A. K. (1968). Notes on transitivity and theme in English, Part 3. Journal of Linguistics, 4(2), 179-215.

Halliday, M. A. K. (1970). Language structure and language function. In J. Lyons (Ed.), New horizons in linguistics (pp. 140-65). Penguin.

Halliday, M. A. K. (1976). Halliday: System and function in language (G. Kress, Ed.). Oxford University Press.

Halliday, M. A. K. (1977). Ideas about language. In M. A. K.
Halliday (Ed.), Aims and perspectives in linguistics (pp. 32-49). Applied Linguistics Association of Australia.

Halliday, M. A. K. (1978). Language as social semiotic: The interpretation of language and meaning. Edward Arnold.

Halliday, M. A. K. (1985). An introduction to Functional Grammar (1st ed.). Edward Arnold.

Halliday, M. A. K. (1998). An introduction to Functional Grammar (2nd ed.). Edward Arnold.

Halliday, M. A. K., \& Matthiessen, C. M. I. M. (2014). Halliday's introduction to Functional Grammar (4th ed.). Routledge.

Hasan, R. (1996). Ways of saying: Ways of meaning (C. Cloran, D. Butt \& G. Williams, Eds.). Cassell.

Hoang, V. V. (1997). An Experiential Grammar of the Vietnamese clause: A functional description [Doctoral dissertation, Macquarie University].

Hoang, V. V. (2012). An Experiential Grammar of the Vietnamese clause. Vietnam Education Publishing House.

Kaplan, J. (1995). English grammar: Principles and facts (2nd ed.). Prentice Hall, Inc.

Le, D. N. (1980). Modality in English and Vietnamese: A systemic comparison [Unpublished master's thesis]. University of Sydney.

Lyons, J. (1979). Introduction to theoretical linguistics. Cambridge University Press.

Martin, J. R., \& White, P. R. R. (2005). The language of evaluation: Appraisal in English. Palgrave Macmillan.

Matthiessen, C. M. I. M. (1995). Lexicogrammatical cartography: English systems. International Language Sciences Publishers.

Matthiessen, C. M. I. M., Teresa, K., \& Lam, M. (2010). Key terms in Systemic Functional Linguistics. Continuum.

Nguyen, D. H. (1979). 201 Vietnamese Verbs. Barron's Educational Series.

Palmer, R. F. (1980). The English verb (8th ed.). Longman.

Shore, S. (1992). Aspects of Systemic Functional Grammar of Finnish [Doctoral Dissertation, Macquarie University]. http://citeseerx.ist.psu.edu/viewdoc/download?doi=10. 1.1.129.1396\&rep=rep1\&type $=$ pdf

Svartvik, J. (1966). On voice in the English verb. Mouton.

Thompson, L. C. (1985). A Vietnamese Reference Grammar. Mon-Khmer Studies Journal, 13-14, 1-367.

\section{French}

Bouchet, A. (1912). Cours elementaire D'annamite. Imprimerie d'Extrême-Orient.

Cordier, G. (1932). Cours de la langue Annamite. Annee preparatoire: Grammaire et exercises. (N.Pub).

Grammont, M., \& Le, Q. T. (1911). Études sur la langue Annamite. In Mémoires de la société de linguistique de Paris (Vol. 17). Imprimerie Nationale.

Truong, V. K. (1867). Abrégé de Grammaire Annamite. Imprimerie Impériale. 


\title{
Appendix
}

\section{Sources of Data for Illustration}

\author{
[NB] = Nguyễn Bản (1995). Tầm tã mưa ơi. Trong Nhũng truyện ngắn hay (tr. 79-104). Nxb Công an nhân dân. \\ $[\mathrm{NHT}]=$ Nguyễn Huy Thiệp (1993). Thương nhớ đồng quê. Trong Truyện ngắn hay (tr. 176-197). Nxb Văn học. \\ $[\mathrm{NKT}]=$ Nguyễn Kim Thản (1977). Động tù̀ trong tiếng Việt. Nxb Khoa học Xã hội. \\ $[N M C]=$ Nguyễn Minh Chính (1993). Mẹ chồng tôi. Trong Truyện ngắn hay (tr. 199-223). Nxb Văn học. \\ $[\mathrm{NM}]=$ Nguyễn Một (1996). Tha Hương. Văn nghệ trẻ, (18). \\ [TĐ] = Tản Đà (1920). Cảm thu, tiễn thu. Thi viện. Truy cập ngày 20-8-2020 tại \\ https://www.thivien.net/T\%E1\%BA\%A3n-\%C4\%90\%C3\%A0/C\%E1\%BA\%A3m-thu- \\ ti\%E1\%BB\%85n-thu/poem-vNz_E1BYhJPvwrJfcXPkPw \\ $[\mathrm{TH}]=$ Tô Hoài (1995). Tuyến tập Tô Hoài. Nxb Văn học. \\ [TDP] = Trần Duy Phiên (1995). Ngõ đạo miền hoang dã. Trong Nhũng truyện ngắn hay (tr. 145-188). \\ Nxb Công an nhân dân.
}

\section{PHẠM TRÙ DẠNG TRONG TIẾNG VIẸT: MÔ TẢ THEO LÍ THUYẾT CHỨC NĂNG HỆ THỐNG}

\author{
Hoàng Văn Vân \\ Trung tâm Nghiên cứu giáo dục ngoại ngũu, ngôn ngũ và quốc tế học, \\ Truòng Đại học Ngoại ngũ, ĐHQGHN, \\ Phạm Văn Đồng, Cầu Giáay, Hà Nội, Việt Nam
}

Tóm tắt: Bài viết này mô tả phạm trù dạng - một trong những khái niệm ngữ pháp khó nắm bắt nhất trong ngữ pháp tiếng Việt dường như chống lại bất kì cách xử lí thoả đáng nào. Khung lí thuyết được sử dụng để mô tả và giải thích phạm trù này là $\mathrm{Ngôn}$ ngữ học chức năng hệ thống. Ba câu hỏi hình thành nên cơ sở của bài viết này là: (1) "Hệ thống DẠNG có tồn tại trong tiếng Việt không?"; nếu có thì (2) "Các sự lựa chọn tỉnh tế có sẵn trong môi trường của phạm trù DẠNG trong tiếng Việt là gì?"; và (3) "Các sự lựa chọn tinh tế này được phân biệt như thế nào nhìn từ quan điểm Ngôn ngữ học chức năng hệ thống?" Câu trả lời cho ba câu hỏi này cho thấy, khác với các các mô tả của ngữ pháp hình thức, DANG tồn tại trong tiếng Việt như là một hệ thống; môi trường hệ thống DẠNG mở ra một số sự lựa chọn tinh tế; và những sự lựa chọn tinh tế này có thể được phân biệt theo ba siêu chức năng ngôn ngữ: siêu chức năng trải nghiệm, siêu chức năng liên nhân, và siêu chức năng văn bản. Nghiên cứu cũng chỉ ra rằng Ngôn ngữ học chức năng hệ thống là khung lí thuyết rất phù hợp để mô tả và giải thích phạm trù DANG trong tiểng Việt: Lí thuyết chức năng hệ thống giúp chúng ta nghiên cứu phạm trù ngữ pháp từ nhiều chiều kích khác nhau, giúp chúng ta có một cái nhìn toàn diện hơn về phạm trù đó. Nghiên cứu này góp phần vào việc ứng dụng lí thuyết $\mathrm{Ngôn}$ ngữ học chức năng hệ thống vào mô tả ngữ pháp tiểng Việt một ngôn ngữ phi Ân-Âu, mở ra tiềm năng mới cho một cách tiếp cận toàn diện đối với việc mô tả ngữ pháp tiểng Việt theo lí thuyết Ngôn ngữ học chức năng hệ thống, phục vụ cho các mục đích nghiên cứu, ứng dụng và giảng dạy.

Tư khoá: hệ thống DẠNG trong tiếng Việt, khiến tác, chuyển tác, thức, đề ngữ 